\title{
Predicting Job Dissatisfaction among Community Junior Secondary School Teachers in Botswana
}

\author{
M. N. Isaiah ${ }^{1}$, H. J. Nenty ${ }^{2}$ \\ ${ }^{1}$ Ministry of Education, Molepolole, Botswana \\ ${ }^{2}$ Department of Education Foundations, University of Botswana, Gaborone, Botswana \\ Email: \{mphoisaiah, hjnenty\}@yahoo.com
}

Received December $24^{\text {th }}, 2011$; revised January $25^{\text {th }}, 2012$; accepted February $16^{\text {th }}, 2012$

\begin{abstract}
African governments tend to refuse to accept the obvious truth that dissatisfaction among teachers has contributed significantly to their inability to attain their educational goals at all levels. A disgruntled worker cannot put in assiduous effort at achieving set goals, especially goals whose levels of achievement are not readily obvious. The spirit underlying the natural pride of contributing to the growth and development of human beings is greatly robbed by the dissatisfaction among teachers. This study tries to determine what factors predict this dissatisfaction among teachers in community junior secondary schools in the South Central Region of Botswana. To determine these for teachers in the 55 community junior secondary schools in the South Central Region of Botswana, a validated 68-item questionnaire with 6Likert-type options designed to measure level of job satisfaction and factors that influence it were administered to 255 teachers from 12 randomly selected schools in the area. A stepwise regression analysis of the resulting data showed that of the nine variables that combine to account for $57 \%$ of the variability in the level of teacher's job dissatisfaction, refusal by parents to be involved in the education of their children accounted for $34 \%$ of such variance. The findings were discussed and recommendations made.
\end{abstract}

Keywords: Teachers' Job Dissatisfaction; Teachers' Commitment; Parental Involvement; Tendency to Leave Teaching

\section{Introduction}

Teachers occupy a prime of place in all efforts at operationalizing formal education. They are the hub around which the process of educating revolves and the education of a nation cannot be of a quality higher than that sustained by the knowledge and devotion of her teachers. Governments across Africa tend to refuse to accept the obvious truth that dissatisfaction among teachers has contributed significantly to their inability to attain the educational goals at all levels. But this is a fact. A disgruntled worker cannot put in assiduous effort at achieving set goals, especially goals whose levels of achievement are not readily obvious.

Job dissatisfaction has been cited in literature as a contributing factor to the lack of commitment and high level of absenteeism among teachers. It is therefore an important factor to consider in educational management and development (Evans, 1998). Teacher job dissatisfaction arises when the physical and psychological benefits that accrue from a teacher's job fall short of his/her expectation. It occurs when a teacher derives a negative or un-pleasurable emotional response from his/her subjective appraisal of his/her current job situation (Siegel \& Lane, 1982). It provokes several negative affective feelings about one's job and these have been shown to have negative influences on one's affective and cognitive dispositions towards such jobs. The spirit underlying the natural pride of contributing to the growth and development of human beings is greatly robbed by feeling of dissatisfaction among teachers.

Frameworks for understanding learners' academic achievement often consider teacher cognitive quality to be key input but of greater importance is the affective disposition of such teachers to put in assiduous effort to ensure that learning takes place. When teacher satisfaction is treated as a dependent variable in a study like this several factors compete for inclusion as those that underlie the level to which teachers are satisfied. A high level of satisfaction is necessary to motivate teachers to invest their cognitive and affective capital for desirable results in the teaching-learning process. Such factors can be grouped under administration-related, learner-related, parent-related; peerrelated, personal and professional factors. In any workplace satisfaction provides the intrinsic foundation for aspiration to achieve

\section{Theoretical Background}

Employees have different needs for which they have psychological inner urge to satisfy. Satisfaction or dissatisfaction is a psychological response which can be understood through theories of motivation. There are four sets of theories recognised when dealing with job satisfaction. These set the context for the study and begin with the categories of motivation theories. Motivational theories are divided into two categories. These are content and process theories. These theories are briefly discussed below to provide a contextual background to the problems of this study. The basic premise of content theories is the belief that job satisfaction is achieved mainly by meeting the needs of employees. It assumes that all individuals possess the same set of needs and therefore prescribe the characteristics that ought to be present in jobs. The two major theories in this category are Maslow's hierarchy of needs and Herzberg's two-factor theory. 
Maslow's concept of motivation as reported by Owen (1995) puts human needs in a hierarchical order. According to this theory, human needs are stratified and when the lower needs are met the desire to fulfill the next level becomes high. The lower level or physiological needs should be satisfied before advancing to the next or higher level needs. So, in order for teachers to be satisfied and perform their job perfectly, first and foremost their physiological needs must be met. A teacher should first have his/her basic needs of food, clothing and shelter met, before he/she can be expected to perform his/her duties effectively. The next level of needs - safety needs, which describes the teachers' feeling of physical and psychological safety and security. Safety also in financial matters, could affect teachers' motivation and performance. Those who feel insecure in any way may be pre-occupied with this goal than being focused on the job.

Social affiliation or belonging needs describes the desire to be accepted and belong to a particular group. Men and women are social beings and as such have needs to be part of a social group, formal or informal, and so are teachers. This means that if teachers feel isolated from others, their satisfaction level will be negatively affected. Esteem needs refer to recognition and pride. The National Commission on Education (Botswana, 1993) indicated that teachers have low status, and their motivation and morale were also considered low, indicating low self-esteem. Finally, the progression leads to the need to realise one's full potential, which is termed self-actualization. Only a small proportion of the population achieves this level. This theory was not intended as an explanation of motivation in the workplace; however, many managerial theorist have enthusiastically adopted it. The theory suggests that employees will always tend to want more from their employers. When they have satisfied the subsistence needs, they strive to fulfill security needs. When jobs are secure they will seek ways of satisfying social needs and if successful will seek the means to the ultimate end self actualization. In such cases, being given autonomy at work before other basic needs are met cannot motivate teachers. If teachers are to perform, then their lower level needs must first be satisfied.

Despite the fact that there are some similarities, Herzberg's (1968) theory unlike Maslow's (1970), does not regard motivation as a single dimension that can be described by a hierarchy of needs. He grouped needs into two groups: the first group deals with hygiene/maintenance factors and motivators. The hygiene/maintenance factors were seen as dissatisfiers as their absence causes dissatisfaction. This included salary, security, working conditions, fringe benefits, policies of education and administration, and interpersonal relationships. According to Herzberg's theory, satisfying these factors will remove dissatisfaction but would not motivate the employees (Mondy, Sharplin, \& Premeaux, 1991). Hygiene factors were seen to produce an acceptable working environment but their absence was believed to cause job dissatisfaction.

The second group of needs is the motivators or satisfiers. These factors are intrinsic to the job. They are related to the job content and include meaningful and challenging work, recognition for accomplishment, feeling of achievements, increased responsibility, and opportunity for growth and advancement and the job itself. According to Herzberg's theory, the absence of hygiene factors results in dissatisfaction. Similarly, the presence of motivating factors cause job satisfaction and their absence create job dissatisfaction (Owens, 1995).
The credibility of Herzberg's two-factor theory has been a matter of debate. Regardless of the debate, the theory has a great impact on management. It is acknowledged for attracting attention to the job content, which is important in the understanding of job satisfaction and motivation. However, critics of this theory argue that it is method bound (Owens, 1995). A person may be dissatisfied with part of the job yet found it acceptable to continue in the profession and Herzberg's theory assumes that a direct relationship exists between job dissatisfaction and productivity.

What the process theories have in common is an emphasis on the cognitive process in determining employee's level of motivation. These theories, which include equity, goal setting and expectancy attempt to explain job satisfaction through the processes that occur in the generation of satisfaction, and by implication, job dissatisfaction.

The equity theory assumes that one important cognitive process involves people looking around and observing what effort other people are putting into their work and what rewards follow them. This social comparison process is driven by individuals concern for fairness and equity. Research had shown that this theory is one of the most useful frameworks for understanding work motivation.

The expectancy theory was popularised by Vroom (1964). He defined the theory as the approach to motivation that attempts to explain behaviour in terms of an individual's goals, choices and the expectations of achieving the objectives (Mondy, Sharplin, \& Premeax, 1991). The theory has become commonly acceptable for explaining how individuals make decisions regarding various behavioural alternatives. It assumes that behaviour results from conscious choices among alternatives whose purposes it is, to make pleasure and minimise pain. According to Scholl (2002) the theory suggests that the relationship between people's behaviour at work and their goals was not as simple as was first imagined. Scholl (2002) indicated that an employee's performance is based on individual factors such as personality, skills, knowledge, experiences and abilities.

Motivation is defined as the psychological force that energizes, directs and sustains behaviour in a work environment. It is behaviourally specific, that is, it is more appropriate to think in terms of an individual's motivation to excel in a particular job requirement or even to carry a specific behaviour than it is to think about an individuals' overall motivation. It must be noted that in life people are not always motivated in every situation. While individual dispositional variables may affect an individual's motivation level at any particular time, motivation itself is not a dispositional variable.

Expectancy theory is therefore used to help understand how individuals make decisions concerning various behavioural patterns. According to Davies and Newstrom (1985), expectancy theory offers the following propositions that when deciding among behavioural options, individuals select the option with the greatest motivation force. The motivational force for behaviour, action, or task is a function of three distinct perceptions: Expectancy, instrumentality and valence.

The researcher's understanding of these theories will assist in the acknowledgement of the perceptions and attitudes of teachers towards their teaching job and provides the researcher the foundation on which to speculate and predict possible solutions to the problems of teachers' dissatisfaction. Aspects of several theories, for example, content theories including Maslow's, (1954) hierarchy of needs theory and Herzberg's, (1968) moti- 
vator/hygiene two-factor theory; process theory (Campbell, Dunnettee, Lawler \& Weik, 1970); opponent-process theory (Landy, 1978), expectations and equity theory (Pinder, 1998) and work adjustment theory (Lofquist \& Dawis, 1969) all have bearings on job dissatisfaction of teachers. An analysis of these theories provides the foundation for this study.

\section{The Problem and Purpose of the Study}

Teaching in Botswana is characterized by low levels of job satisfaction, low morale, low status and an attitude that regards the teaching profession as a last resort employment. The refusal by some teachers to be involved in extracurricular activities and study supervision and constant confrontation with educational authorities are clear signs that there is a problem in the profession. The uncompromising stance taken by teachers is a source of concern to the authorities, to students as recipients of education, to parents as stakeholders and to the nation at large. It is important to acknowledge that teachers in Botswana are still left disgruntled despite all the attempts to pacify them. It is clear that the teachers' dissatisfaction, low levels of motivation and morale are worrisome as these have been a mention in the two National Commissions of Education (Republic of Botswana, 19977, 1993).

Following from these, this study aims at predicting job dissatisfaction among teachers in community junior secondary school in the South Central Region of Botswana. It will determine what factors significantly predict these feelings of dissatisfaction among teachers in community junior secondary schools in the South Central Region. Teachers' perceptions and their professional levels in community junior secondary school were investigated to find out if they were having any bearing on teachers' job dissatisfaction. The study also explored the administrative factors influencing teachers' job dissatisfaction.

\section{Research Questions and Hypotheses}

The study intends to find answers to the following two questions:

1) To what extent are teachers in community junior secondary schools in the South Central Region of Botswana dissatisfied with their jobs?

2) What factors significantly predict job dissatisfaction among community junior secondary school teachers' in South Central Region of Botswana?

This is done through testing two null hypotheses. One, that teachers in community junior secondary schools in South Central Region of Botswana are not significantly dissatisfied, and two, that the level to which teachers in community junior secondary schools in South Central Region of Botswana are dissatisfied with their job is significantly predicted by:

1) The level to which training opportunity is available to them;

2) Level to which their achievement is recognized;

3) The quality of supervision by superiors;

4) Their workload;

5) Level of community support;

6) Level of availability of facilities;

7) Availability of accommodation;

8) Quality of relationship with Management;

9) Quality of relationship with students;

10) Availability of promotional opportunities;
11) Students' progression;

12) Level of sense of belonging;

13) Level of self actualization;

14) Level to which school climate is conducive;

15) Level of parental involvement;

16) Level of job security;

17) And level of adequacy of salary.

\section{Significance of the Study}

Determining the factors that have significant influence teachers' job dissatisfaction has multiple benefits to the profession, the ministry of education, to policy formulation and implementation as well as to the teacher themselves. It is crucial to find out the factors predicting teachers' job dissatisfaction in community junior secondary school for purpose of establishing properly directed educational data for use by policy makers and policy implementers. It is pertinent to carry out this study now, since the teaching profession is looked down upon by the society and the level of disgruntlement among teachers is worrisome.

\section{Research Methodology}

In this study a survey method was used since the population of teachers in all community junior secondary schools in the South Central Region is spread over a wide area. The use of a survey inferential approach was appropriate, as the research opted to study different perceptions of teachers spread throughout a wide area and what these teachers see as the factors that influence their job dissatisfaction. A purposive random sampling technique was used to pick 255 teachers from 12 randomly selected schools in the area. These served as the participants for the study.

Researcher-developed and validated 66-item 6-point Likerttype questionnaire was used to collect the data for this survey inferential study. Besides measuring the dependent variable, level of teacher dissatisfaction, the instrument also provided for the measurement of several independent variables which were called for in the thesis from which this paper emanates. These were:

1) Availability of training opportunity (5 items);

2) Level of achievement of recognition (4 items);

3) Quality of supervision by superiors (4 items);

4) Teacher workload (4 items);

5) Level of community support (4 items);

6) Level of availability of facilities (4 items);

7) Availability of accommodation (4 items);

8) Quality of relationship with management (4 items);

9) Quality of relationship with students (4 items);

10) Availability of promotional opportunities (4 items);

11) Students' progression (4 items);

12) Level of sense of belonging (4 items);

13) Level of self actualization (4 items);

14) Level to which school climate is conducive (4 items);

15) Level of parental involvement (5 items);

16) Level of job security (5 items);

17) Level of adequacy of salary (4 items).

The split half reliability estimate for the variables involved in the study ranged from .81 for quality of supervision to .93 for level of adequacy of salary. In order to collect data for this study a survey method was used. The use of a survey inferential 
approach was appropriate, as the research opted to study different perceptions of a sample of 255 teachers spread throughout a wide area based on which a generalization was made to the entire population of 2,244 teachers in the region.

\section{Data Analysis and Findings}

To answer the first research question, Hypothesis 1 was tested in the null form by performing a population t-test statistical analysis (see Table 1). The analysis gave a t-value of 19.74 which given 254 degrees of freedom was found to be significant at beyond .01 level.

The null hypothesis was therefore rejected meaning that teachers in community junior secondary schools in the South Central Region of Botswana are significantly dissatisfied with their jobs. It is worthy of note to observe that only $2.8 \%$ of the responding teachers disagreed with the statement "I will leave teaching if I find a better employment"

The second research question was answered by testing the second hypothesis in the null form. This was done by carrying out a stepwise regression analysis using the SPSS computer package (see Table 2). Data from all the 17 variables measured were plugged into the prediction analysis and nine of them were identified as making a significant independent contributions to the prediction of job dissatisfaction among community junior secondary school teachers' in South Central Region of Botswana. These were: parental involvement, level of achievement of level to which school climate is conducive, level of job security, and adequacy of salary (see Table 2). These nine variables accounted for a total of $57.2 \%$ of the total variability in job dissatisfaction among community junior secondary school teachers in South Central Region of Botswana

\section{Discussions}

In the resulting multiple regression model, parental involvement accounted for $33.9 \%$ of the variation in teacher job dissatisfaction. After parental involvement, the level to which a teacher perceives that he/she is achieving recognition accounted for an additional $11.4 \%$ of the total variation and the quality of supervision by superiors accounted for additional 3.0\%. After these the percentage of the variance accounted for independently by the other six predictor variables were: level of teacher workload, $2.2 \%$; level of self actualization, $1.9 \%$; level of belonging, $1.4 \%$; level to which school climate is conducive, $1.3 \%$; level of job security, $1.0 \%$; and adequacy of salary, $1.1 \%$ (see Table 2). Each of these indicates a significant contribution to the prediction of dissatisfaction among teachers.

The findings of this study indicate that nearly $96 \%$ of teachers were generally dissatisfied with the teaching profession and $97.2 \%$ given the opportunity, would leave for another job. The many and varied factors that predict teachers' dissatisfaction show the complexity of teaching as a profession. Teaching is a profession with multi-dimensional roles. Enhancing learner's cognitive growth cannot be achieved under an indiscipline and non- conducive environment which teachers are to create and maintain. A child is a bundle of cognitive, affective and psychomotor potentials which education is to bring out and develop. For example, child cannot learn that for which he/she is not affectively prepared. Unlike lecturers, teachers do not just teach but facilitate learning. That is, they go further than just imparting knowledge, information and understanding, like lec- turers do. First of all, they have to prepare the learners to take in that which is imparted, and at the end, take additional steps to ensure that what is imparted is taken in. He must be an expert in knowledge acquisition, expert in teaching design, planning and methodology, in classroom assessment, and in policing duties. Sometimes they play 'baby sitting' roles, mentoring roles, a coach roles, in fact teachers are said to play twelve different roles (Harden \& Crosby, 2000). This is why significant factors that predict dissatisfaction among community junior secondary school teachers in Botswana actors are many and varied. To satisfy their multidimensional roles effectively, teachers must secure the support of students, parents, supervisors and administrators. The absence of such support renders the teacher dissatisfied and hence ineffective. Their wish to leave the profession hinges on the fact that they are expected to satisfy all these roles and yet their physiological, social and self actualization needs are not met, neither do they have maximum support from the student administration, supervisors and parents. The findings of this study confirm this. Teachers would rather leave teaching than to stay in and do a lousy job because they are not physiologically and psychologically equipped to do the type of job that would satisfy their conscience.

Lack of satisfaction brought about by the factors identified in the study has a negative impact on the teaching profession among community secondary school teachers in Botswana. This confirms findings by Orlando (2000) that if teachers' work place is not conducive to them it will influence their desire to quit the profession. This observation also concurs with Bame (1991), that teachers were leaving the profession because of lack of recognition and poor work conditions. Garber (2005) noted that dissatisfaction among teachers was a result of the overload, burnout and poor management. The fact that teachers were concerned with the conditions of service positively contributed to teachers' dissatisfaction with their career. Within the education systems of many developing countries teachers are expected to provide a service to the nation without disgruntlement as they are dealing with children most of their time. The products of teachers' labor is not instantly obvious, hence the society tends to have limited vision of their worth and hence have limited recognition of their effort.

The first predictor, parental involvement, was found to account for $33.9 \%$ of the variability in level of teachers' dissatisfaction. This puts parental involvement at the limelight among factors that influence their dissatisfaction. Teachers play the role of parents in the mornings and early afternoon, but parents refused to play their role as educators, partners in children development at any time. They rarely attend parent-teachers meetings nor even inquire from their children how well they are doing in school. Not to talk of visiting the schools once a while to inquire about the welfare and academic performance of their kids. But a review of findings from several studies shows that " $86 \%$ of the public believes that support from parents is the most important way to improve schools" and "lack of parental involvement is the biggest problem facing the schools" (Rose, Gallup \& Elam, 1997). The absence of parental support is detrimental to the development of the learner and hence the satisfaction of the teachers. This revealed that parents rarely come to visit the school even when officially invited for consultation meetings. Further inquiry revealed that few parents come to school for consultations with teachers and this negatively contribute to the current bad behaviour exhibited by students Judging from these results it can be concluded that according to 


\section{N. ISAIAH ET AL.}

Table 1.

Population t-test analysis of the level to which teachers from the south central region of Botswana are dissatisfied with their job $(\mathrm{n}=$ 255).

\begin{tabular}{ccccccc}
\hline Variable & Expected mean & Observed mean & Std Dev. & $\mathrm{df}$ & $\mathrm{t}$-value & $p<$ \\
\hline Level of job dissatisfaction & 17.50 & 21.14 & 2.94 & 254 & $19.74 *$ & .000 \\
\hline Critical $\mathrm{t}=2.58$ for $\alpha=.01$. & & & & & &
\end{tabular}

Table 2.

Regression analysis using ANOVA to determine the factors predicting teachers' job dissatisfaction ${ }^{\mathrm{j}}$.

\begin{tabular}{|c|c|c|c|c|c|c|c|}
\hline Model & Source of Variation & Sum of Squares & $\mathrm{df}$ & Mean Square & $\mathrm{R} / \mathrm{R}^{2}$ & F & Sig. \\
\hline \multirow{3}{*}{1} & Regression & 746.354 & 1 & 746.354 & $582^{\mathrm{a}} / .339$ & 129.882 & $.000^{\mathrm{a}}$ \\
\hline & Residual & 1453.842 & 253 & 5.746 & & & \\
\hline & Total & 2200.196 & 254 & & & & \\
\hline \multirow{3}{*}{2} & Regression & 996.159 & 2 & 498.080 & $.673^{\mathrm{b}} / .453$ & 104.246 & $.000^{\mathrm{b}}$ \\
\hline & Residual & 1204.037 & 252 & 4.778 & & & \\
\hline & Total & 2200.196 & 254 & & & & \\
\hline \multirow{3}{*}{3} & Regression & 1062.889 & 3 & 354.296 & $.695^{\mathrm{c}} / .483$ & 78.192 & $.000^{\mathrm{c}}$ \\
\hline & Residual & 1137.307 & 251 & 4.531 & & & \\
\hline & Total & 2200.196 & 254 & & & & \\
\hline \multirow{3}{*}{4} & Regression & 1111.701 & 4 & 277.925 & $.711^{\mathrm{d} / .505}$ & 63.832 & $.000^{\mathrm{d}}$ \\
\hline & Residual & 1088.495 & 250 & 4.354 & & & \\
\hline & Total & 2200.196 & 254 & & & & \\
\hline \multirow{3}{*}{5} & Regression & 1152.482 & 5 & 230.496 & $.724^{\mathrm{e}} / .524$ & 54.780 & $.000^{\mathrm{e}}$ \\
\hline & Residual & 1047.714 & 249 & 4.208 & & & \\
\hline & Total & 2200.196 & 254 & & & & \\
\hline \multirow{3}{*}{6} & Regression & 1183.199 & 6 & 197.200 & $.733^{\mathrm{f}} / .538$ & 48.088 & $.000^{\mathrm{f}}$ \\
\hline & Residual & 1016.997 & 248 & 4.101 & & & \\
\hline & Total & 2200.196 & 254 & & & & \\
\hline \multirow{3}{*}{7} & Regression & 1213.311 & 7 & 173.330 & $.743^{\mathrm{g}} / .551$ & 43.382 & $.000^{\mathrm{g}}$ \\
\hline & Residual & 986.885 & 247 & 3.995 & & & \\
\hline & Total & 2200.196 & 254 & & & & \\
\hline \multirow{3}{*}{8} & Regression & 1234.151 & 8 & 154.269 & $.749^{\mathrm{h}} / .561$ & 39.284 & $.000^{\mathrm{h}}$ \\
\hline & Residual & 966.046 & 246 & 3.927 & & & \\
\hline & Total & 2200.196 & 254 & & & & \\
\hline \multirow{3}{*}{9} & Regression & 1258.793 & 9 & 139.866 & $.756^{\mathrm{i}} / .572$ & 36.400 & $.000^{\mathrm{i}}$ \\
\hline & Residual & 941.403 & 245 & 3.842 & & & \\
\hline & Total & 2200.196 & 254 & & & & \\
\hline
\end{tabular}

$\mathrm{R}=.756 ; \mathrm{R}^{2}=.572 .{ }^{\mathrm{a} P r e d i c t o r s}$ (Constant), Parental involvement; ${ }^{\mathrm{b}}$ Predictors: (Constant), Parental involvement, Achievement of recognition; ${ }^{\mathrm{c}}$ Predictors: (Constant), Parental Involvement, Achievement of recognition, Quality of supervision; ${ }^{\mathrm{d}}$ Predictors: (Constant), Parental Involvement, Achievement of recognition, Quality of supervision, Teacher workload; 'Predictors: (Constant), Parental Involvement, Achievement of recognition, Quality of supervision, Teacher workload, Self actualization; ${ }^{\mathrm{f}}$ Predictors: (Constant), Parental Involvement, Achievement of recognition, Quality of supervision, Teacher workload, Self actualization, Level of belonging; ${ }^{g}$ Predictors: (Constant), Parental Involvement, Achievement of recognition, Quality of supervision, Teacher workload, Self actualization, Level of belonging, Level to which school climate is conducive; ' Predictors: (Constant), Parental Involvement, Achievement of recognition, Quality of supervision, Teacher workload, Self actualization, Level of belonging, Level to which school climate is conducive, Job security; 'Predictors: (Constant), Parental Involvement, Achievement of recognition, Quality of supervision, Teacher workload, Self actualization, Level of belonging, Level to which school climate is conducive, Job security, Adequacy of salary; 'Dependent Variable: Level of Teachers' Dissatisfaction. 
teachers' perception the higher the level of parental involvement the lower the teachers' level of job dissatisfaction tends to be.

Teachers also mentioned that schools must create a conducive environment that can facilitate a two-way communication and trust between parents and teachers. This indicates that schools have created a threatening set up which does not facilitate communication between teachers and the parents of their students. This lack of confidence on the part of teachers/parents, and in some cases poor understanding of exactly what is it that each part is supposed to do has led the parents to minimally support or being involved in school management. However, according to expectations of the partnership policy that is brought about by the child, one can argue that discussions of students' academic performance and discipline demand parents to be supportive of teachers. Although teachers argue for more parental involvement Haar (1999) agrees that for better or for worse, parental involvement plays an extremely important role in the education of their children. In Botswana (Botswana, 1993), education leaders and other stakeholders advocate for parental involvement as a way of raising the level of student achievement.

On the question of school climate, Andian (1990) described a conducive school climate as a place where resources are easily accessible, information flows freely to all staff, environment is free of threats and transparency and openness are treated as key values. The teachers noted that they were highly dissatisfied and frustrated with the conditions of service in the schools. They spoke scathingly of management teams, whom they said lacked vision, purpose and were ineffective. Vail (2005) indicated that those in leadership had deficiencies which affect the quality of service delivery. Teachers were therefore frustrated by the work place environments created by leadership in schools.

According to Chapman, Snyder and Burchfield (1992) instructional leadership can positively or negatively influence teachers' level of job dissatisfaction. The findings of this study reveal that instructional supervision in schools contributes to teachers' level of job dissatisfaction. Since those in management play a pivotal role in the day to day running of the school (Hom \& Kinicki, 2001), the high level of teachers' satisfaction implies that school managers are failing in carrying out their duties effectively. According to Nias, Southworth, and Yeomans (1989) school management teams are pivotal in schools and have greater influence the culture of the school. This agrees with Cooke's (2001) contention that assessment of teachers by school management teams are necessary to uphold the skills and knowledge brought by teachers. Teachers noted that leadership in school is determined by or hinges upon personalities of individuals in the management team and how they relate with their subordinates.

\section{Implications, Conclusions and Recommendations}

The findings from this study provide several implications for administrators and policy makers in education. First though teaching in Botswana is considered by most people as a well paid and stable job, it is surprising to note that teachers in our sample expressed significant level of job dissatisfaction with their job as whole. Though some studies done by Locke (1984) suggested that that money is the most powerful motivator, it seems that it will motivate to the extent that is seen as being able to satisfy an individual's personal goals. The finding of this study is saying that teachers are not merely working only for money, teachers as professionals start their work with certain aspirations and expectations which if not met will result in dissatisfaction. Secondly, teachers were significantly dissatisfied with the level and quality of parental involvement, lack of recognition for achievement, poor supervision, lack of training opportunities, salary and many other predictors.

The study has also revealed that, in those passing years in Botswana, government has not done enough to meet the needs of secondary school teachers at this level of education in this respect. What makes the situation even worse is that promotion processes in schools are perceived by teachers as unfair, irrational and not based on competence. If the government remains indifferent to this facet of job satisfaction and does nothing, this will probably continue to be the main source of job dissatisfaction among teachers at junior secondary school.

Thirdly, inconsistent findings are observed here with respect to the facet of supervision. However, the discrepancy can be explained by change in organizational structures of most schools in the past ten years. Our schools need to move from a centralized power which extremely gives the school principal the absolute authority which cannot be questioned by his subordinates. Teachers in some schools had no right to participate in decision making process. They are told to follow rules and regulations laid down by school authorities without question, which resulted in a sense of powerlessness and hence dissatisfaction. Such lack of interaction and communication among teachers and their supervisors could explain why teachers reported high dissatisfaction with their supervisors.

Lack of parental involvement also poised a great challenge when it comes to the predictors of teacher job dissatisfaction, parents play a very important role in the education of their children, hence the need for them to participate in learning activities of their wards and assist teachers in enforcing student discipline. Given the very high dependence of teacher satisfaction on parental involvement, there is need for the Ministry of Education to occasionally mount workshops and seminars for parents to enlighten them on their place not only in the learning by their wards but in greasing teachers psychological willingness to teach and derive satisfaction by so doing.

\section{REFERENCES}

Andian, I. (1990). Protest of the undervalued. The Daily News, 10 February $1990,17$.

Bame, K. N. (1991). Teacher motivation and retention in Ghana. Accra: University Press.

Bennell, P. (2004). Teacher motivation and incentives in sub-Saharan African and Asia. URL. http://www.eldis.org/fulltext/dfidtea.pdf

Benner, A. D. (2000). The cost of teacher turnover. Austin, Texas: Texas Center for Educational Research. URL.

http://www.sbec.lx.us/SBECOnline/txbess/turnoverrpt.pdf

Benya, J. R. (2001). Lighting of schools. Washington, DC: National Clearinghouse for Educational Facilities. URL.

http://www.edfacilities.org/pubs/lighting.html

Berry, B., Hopkins-Thompson, T., \& Hoke, M. (2002). Assessing and supporting new teachers: Lessons from the Southeast. North Carolina: The Southeast Centre for Teaching Quality at the University of Carolina.

Billingsley, B. S., \& Cross, L. H. (1992). Predictors of commitment, job satisfaction and intent to stay in teaching: comparison of general and special educators. The Journal for Special Education, 25, 453- 
471. doi: $10.1177 / 002246699202500404$

Buchner, J., \& Hay, D. (1998). Staff induction: Establishing mentorship programmes for academic staff in South African Institutes of Higher Education. South African Journal of Higher Education, 12, 19-35.

Chapman, D. W., Snyder, C. W. \& Burchfield, S. A. (1992). Teacher incentives in the third world. Teacher and Teacher Education, 9, 301-316. doi:10.1016/0742-051X(93)90045-I

Charlwood, A. (2002). Why do non-union employees want to unionise? Evidence from Britain. British Journal of industrial relationship, 40, 463

Conley, S., \& Livingston, R. (1993). Teacher work design and job satisfaction. Education Administration Quarterly, 62, 453-478. doi: $10.1177 / 0013161 \times 93029004004$

Cooke, J. A. (2001). Happy to be here. Logistics Management and Distribution Report, 40, 40-44.

Donnelly, K. (2003). The teaching system needs more than money and smaller classes. URL.

http://www.onlineopinion.com.au/view.asp?article

Evans, L. (1998). Teacher morale, job satisfaction and motivation. London: Sage Publication Company.

Garber, S. (2005). Employee dissatisfaction and turnover: You can't afford to ignore it. URL. http://www.ascrs.org.publication/ao/gabererae

Haar, C. (1999). Teacher union and parent involvement. URL. http://www.policyreview.org/summer'99

Handmaker, W. B. (2005). The web of support: A lesson from spiderman. URL. http://web35.epnet.com/citation.asp?tb

Harden, R. M., \& Crosby, J. R. (2000). The good teacher is more than a lecturer-The twelve roles of the teacher. Medical Teacher, 22, 334347.

Holtz, G. (2002). How to prevent teacher burnout. URL. http://www.sbomagazine.com

Hom, P. W., \& Kinicki, A. J. (2001). Toward a greater understanding of how dissatisfaction drives employee turnover. Academy Management Journal, 44, 975-987. doi:10.2307/3069441

Ingersoll, R. M. (2002). The teacher shortage: A case of wrong diagnosis and wrong prescription. NASSP Bulletins, 86, 16-31. doi:10.1177/019263650208663103

Katcher, B. L. (2003). Benefit pros express growing job dissatisfaction. Employee Benefits News, 17, 9.

Locke, E. A. (1984). Job satisfaction. In M. Gruneberg, \& T. Wall (Eds.), Social psychology and organizational behaviour. New York: John Wiley and Sons.

McCormick, J., \& Solman, R. (1992). Teacher's attributions of responsibility for occupational stress and satisfaction: An organizational perspective. Educational Studies, 18, 201-222. doi: $10.1080 / 0305569920180206$

McQuarie, F. (1999). Professional mystique and journalist dissatisfaction. Newspaper Research Journal, 20, 20-28.

Mercer, D., \& Evans, B. (1991). Professional Myopia: Job satisfaction and management of teachers. School organization, 11, 291-301

Mortimore, P., \& Mortimore, J. (1998). The political and the professional in education: An unnecessary conflict. Journal of Education for Teaching, 24, 205-219. doi:10.1080/02607479819737

National Center for Educational Statistics (NCES) (1997). Statistical analysis report. Job satisfaction among American teachers: Effect of workplace conditions, background characteristics and teachers compensation. URL. http://nces.ed.gov/pubs97/97471.pdf

Nias, J., Southworth, G., \& Yeomans, R. (1989). Staff relationships in the primary school: A study of organisational cultures. London: Cassell.

Orlando, F. L. (2000). Teacher recruiting, retention and from rewarding of teachers. URL. http://www.columbiagroup.org/recruiting6.htm

Patrick, J. E. (1995). Correlation between administrative styles and school climate. EDRS, Accession Number ED387853.

Republic of Botswana. (1977). Report on the national commission on education. Ministry of Education, Gaborone: Government Printer.

Republic of Botswana. (1993). Report on the national commission on education. Ministry of Education, Gaborone: Government Printer.

Reyes, P., \& Imber, M. (1992). Teachers perception of the fairness of their workload and their commitment, job satisfaction and morale: implications for teacher evaluation. Journal of Personnel Evaluation in Education, 8, 291-302. doi:10.1007/BF00125243

Siegel, L., \& Lane, I. M. (1982). Personnel and organisational psychology. Homewood III: Richard D. Irwin, Inc.

Tarifa, F. N., \& Kloep, M. (1994). Working conditions, work style and job satisfaction among Albanian teachers. International Review of Education, 40, 159-172. doi:10.1007/BF01103691

Taylor, D. L., \& Tashakkon, A. (1994). Predicting teacher' sense of efficacy and job satisfaction using school climate and participatory decision-making. The Annual Meeting of the Southeast Research Association, San Antonio, January 1994.

Teacher Recruiting. (2005). Teacher recruiting and retention. URL. http://www.columbiagroup.org/recruiting

Tye, B. B., \& O'Brien, L. (2002). Why are experienced teachers leaving the profession. Phi Delta Kappa, 84, 24-32.

US Board Report. (2005). US job satisfaction keeps falling. The Conference Board Reports Today. URL. http://www.conference-board.org/utilities/press.detail.cfm

Vail, K. (2005). Climate control: Ten ways to make your school great place to work and learn. URL. http://www.asbj.com/executive/0695ASBJvail/.pdf 